Syntax Fusion : Jurnal Nasional Indonesia

p-ISSN: -

e-ISSN : 2775-4440

Vol. 1, No. 7, Juli 2021

\title{
DASAR-DASAR AJARAN ISLAM, AL- QUR'AN DAN KESETARAAN GENDER
}

\section{Ikhsan dan Predi M Pratama}

UIN Sunan Gunung Djati Bandung

Email: Ikhsanfaisal0203@gmail.com, predimpratama12@gmail.com

\begin{abstract}
Abstrak
Prinsip kesetaraan gender dalam perspektif Islam adalah bahwa laki-laki dan perempuan adalah sama dalam beberapa hal, yaitu; sebagai hamba Allah, sebagai khalifah Allah, menerima perjanjian primordial, terlibat aktif dalam peristiwa drama kosmik, dan memiliki potensi yang sama untuk berprestasi. Prinsip ini secara jelas dituangkan dalam pedoman ajaran Islam berupa nash atau nash dari Al-Qur'an dan Hadist. Sedangkan perbedaan antara laki-laki dan perempuan hanya dapat dilihat dari tingkat ketaqwaannya kepada Allah SWT. Jurnal ini bertujuan untuk menjelaskan dan menganalisis hubungan Islam dengan gender, sedangkan metode penelitian yang digunakan adalah studi kepustakaan, yaitu serangkaian kegiatan yang berkaitan dengan metode pengumpulan data kepustakaan, membaca dan mencatat serta mengolah bahan penelitian. Sedangkan sumber data dalam penelitian ini diperoleh dari buku, artikel, jurnal dan internet. Sumber data dibagi menjadi dua kategori, yaitu sumber data primer dan sekunder. Sumber data primer yaitu buku dan penelitian terdahulu, kemudian sumber data sekunder yang terdiri dari jurnal, artikel, majalah, literatur, dokumen, dan sebagainya. Kedua macam sumber penelitian tersebut kemudian dijadikan bahan penelitian penulis untuk dianalisis guna menemukan jawaban atas permasalahan yang menjadi fokus penelitian.

Sementara itu, temuan utama dalam penelitian ini adalah pandangan umum tentang gender, pandangan Islam tentang gender, keadilan dalam Islam, konsep bias gender dalam Alquran, kesetaraan gender dalam perspektif Alquran dan prinsip kesetaraan.
\end{abstract}

Kata Kunci: Keadilan Islam, Kesetaraan Gender, Bias Gender dan Keadilan Gender. 


\section{Pendahuluan}

Islam membawa banyak perubahan dalam kehidupan sosilal sehari-hari di dalam masyarakat di antaranya aturan-aturan islam ialah, penghapusan diskriminasi dan pelecehan seksual terhadap wanita, membunuh bahkan mengubur hidup-hidup bayi perempuan yang terjadi pada jaman jahiliyah, semua perkara ini perlahan dapat di hapuskan dengan prinsip dan nilai-nilai islam yang di terapkan oleh Rasulullah s.a.w. Wanita mempunyai hak memastikan mas kawin yang diakui menjadi milik penuh individu wanita. Kemudian, memiliki hak peninggalan atau waris yang sebelumnya diperlakukanebagai peninggalan mendiang suami (Musdah Mulia, 2011). Namun, tidak bisa dipungkiri dalam aturan agama terdapat perbedaan-perbedaan dalam hal pembagian hak, peran, dan tanggung jawab antara pria dan wanita. Namun semua itu sudah dianggap menguntungkan dan adil terhadap perempuan. Terbukti, di sepanjang sejarah, tidak ada umat Islam yang pernah menggugat aturan tersebut.

Baru ketika peradaban Barat masuk ke dunia Islam syariat Islam banyak dikritik dan digugat. Apa yang diyakini oleh umat Islam tentang hak, peran, dan tanggung jawab mendapat tantangan wacana Barat dengan memunculkan isu kesetaraan gender. Tujuannya adalah kebebasan status dan persamaan peran antara laki-laki dan perempuan di segala aspek kehidupan (Nasaruddin Umar, 2001). Sebelumnya sejarah telah menuliskan bahwa jauh sebelum datangnya Islam, telah dikenal adanya dua peradaban besar yaitu peradaban Yunani dan peradaban Romawi. Selain itu, dunia juga mengenal adanya dua agama besar, yaitu Yahudi dan Nasrani. Eksistensi kaum perempuan dalam perputaran waktu pada masa peradaban- peradaban serta agama-agama tersebut memiliki nuansa tersendiri. Hal tersebut secara khusus dapat dilihat dari sisi kesetaraan antara kaum laki-laki dan perempuan, baik dalam hal publik maupun domestik

Puncak peradaban Yunani menggambarkan kaum perempuan diberi kebebasan hanya untuk memenuhi kebutuhan dan selera kaum lelaki, sehingga hubungan seksual bebas tidak dianggap sesuatu yang melanggar kesopanan, dan tempat-tempat pelacuran menjadi pusat-pusat kegiatan politik dan sastra atau seni. Kondisi tersebut sangat mendiskreditkan kaum perempuan, sehingga mereka tidak dapat berekspresi secara alamiah. Selanjutnya dalam peradaban Romawi, kaum perempuan sepenuhnya berada di bawah kekuasaan ayahnya dalam kedudukannya sebagai kepala rumah tangga. Ketika kaum perempuan telah berkeluarga maka kekuasan dalam rumah tangga beralih kepada sang suami.

Adapun tentang hak dan kewajiban wanita dalam agama Yahudi dan Nasrani, dikemukakan bahwa dalam ajaran Yahudi, martabat wanita itu adalah sama dengan pembantu. Ada sekelompok manusia yang menganut ajaran bahwa seorang ayah berhak menjual anak perempuannya selama belum baligh dan anak perempuan tidak menjadi ahli waris dari harta peninggalan ayahnya kecuali kalau dia tidak mempunyai saudara laki-laki. Ajaran mereka menganggap bahwa kaum perempuan itu sumber laknat, karena salah satu asumsi bahwa menurut mereka kaum perempuan yang menyebabkan Adam keluar dari Surga. Sedangkan ajaran agama Nasrani 
menganggap kaum perempuan sebagai senjata iblis untuk menyesatkan manusia dan kaum perempuan dikategorikan sama dengan status anak di bawah umur dan orangorang gila yang tidak mempunyai hak publik penuh.

Dakwah Rasulullah pada awal-awal, masyarakat pertama yang bersentuhan dengan dakwahnya adalah masyarakat Arabb. Masyarakat bangsa Arab pada jaman jahilliayah memandang wanita adalah aib dan tidak ada harganya, secara umum masyarakat Arab tidak senang dengan kelahiran anak perempuan, mereka memperjual belikan bahakan lebih kejam daipada itu mreka mengubur bayi perempuan yang masih hidup. Kedatangan ajaran Islam membawa angin segar bagi kaum perempuan, ajaran Islam menjadi rahmat bagi kaum perempuan karena Islam mengajarkan persamaan antara manusia, baik antara laki-laki dan perempuan maupun antar bangsa, suku dan keturunann. Perbedaan yang hanya dapat terlihat dari tinggi rendahnya nilai pengabdian dan ketakwaannya manusia kepada Tuhan Yang Maha Esa (Lihat Q.S AlHujurat ayat 13).

Kehidupan yang mengisahkan penderitaan bagi kaum perempuan yang dibaluti oleh kondisi tragis yang terkadang tak terlihat oleh mata hati nurani kebanyakan manusia adalah ketika kaum perempuan mengalami kekerasan dalam rumah tangga atau ketimpangan hak asasi manusia antara kaum laki-laki dan perempuan maka muncul wacana baru dalam dunia gender. Sebuah wacana yang memperbincangkan antara kaum laki-laki dan kaum perempuan sebagai makhluk yang sama namun berbeda dari sudut pandang jenis kelamin.

Wacana gender ini menjadi gerbang terlihatnya realitas bahwa kedudukan kaum laki-laki yang selalu identik dengan penguasa alias bak seorang raja dan penentu segala keputusan kini mulai pupus sehingga layak dan patut untuk diperbincangkan. Kondisi terbalik yang terlihat bahwa adanya realitas dalam dunia kaum perempuan yang mulai menggugat keberadaan dan hak mereka dalam ruang publik maupun ranah domestik (Hasnani Siri, 2014).

\section{Metode Penelitian}

Penelitian yang digunakan dalam artikel ini adalah studi pustaka, yaitu kumpulan kegiatan yang berkaitan dengan metode dalam mengumpulkan data pustaka, membaca dan mencatat serta mengolah bahan penelitian. Studi pustaka bukan bertujuan untuk mengajarkan bagaimana seseorang menjadi ahli perpustakaan, tetapi untuk menunjukan penelitian kepustakaan secara garis besar. Pertama-tama akan diuraikan ciri-ciri studi kepustakaan sebagai suatu metode yang otonom, kemudian dilanjutkan dengan pengenalan terhadap sistem klasifikasi koleksi perpustakaan, dan instrumen penelitian perpustakaan seperti alat bantu bibliografis, bibliografi kerja dan tahap-tahap penelitian kepustakaan (Mestika Zed, 2018).

Sumber data dalam penelitian ini merupakan bahan yang penulis gunakan untuk menjawab pertanyaan penelitian. Sumber pengambilan data tersebut diperoleh dari buku-buku, artikel, jurnal dan internet. Sumber data tersebut terbagi dalam dua kategori yaitu sumber data primer dan sekunder. Sumber data Primer yaitu Buku dan penelitian 
terdahulu kemudian sumber data Sekunder yang terdiri dari jurnal, artikel, majalah, literature, dokumen, dan sebagainya. Kedua macam sumber penelitian tersebut kemudian dijadikan bahan penelitian penulis yang akan dianalisis supaya ditemukan jawaban dari permasalahan yang menjadi fokus penelitian.

Tahap berikutnya setelah data terkumpul, penulis mengolah dan menganalisis data tersebut. Tujuan penulis menganalisis data yaitu untuk menyempurnakan serta menyederhanakan berbagai macam data yang telah penulis kumpulkan, kemudian data tersebut disajikan kedalam suatu rancangan yang dibuat secara sistematis, sehingga ketika menafsirkan serta mengolah atau memaknai data yang terkumpul menjadi lebih mudah mengolahnya. Objek atau lebih baik disebut subjek periset kepustakaan terbenam dalam timbunan koleksi perpustakaan berupa teks-teks yang harus dicari dan dikumpulkan serta dibentuk menurut kerangka penelitian yang sudah dibangun sebelumnya. Timbunan bahan bacaan penelitian dalam hutan belantara kata-kata diklasifikasikan berdasarkan kelompok koleksi, disiplin, judul, topik dan sub-topik yang tak terhitung jumlahnya dalam suatu subjek yang ditulis oleh pakar (Mestika Zed, 2018).

\section{Hasil dan Pembahasan}

\section{Gender}

Kenyataan yang mengindikasikan bahwa perempuan masih diposisikan sebagai warga kelas dua masih terlihat di belahan dunia ini. Hal ini terlihat pada aturan, kebiasaan, budaya dan penafsiran agama, yang mengarah pada pengekangan dan perampasan hak-hak perempuan. Tradisi masyarakat Islam ada yang beranggapan bahwa suara perempuan adalah aurat, sehingga interpretasi ini dapat menghalangi kaum pemahaman memiliki akses untuk mengaktualisasikan diri di ranah publik.

Istilah kesetaraan gender dalam tataran praksis memang hampir selalu diartikan sebagai kondisi "ketidaksetaraan" yang melahirkan diskriminasi, subordinasi, penindasan, perlakuan tidak adil, dan semacamnya yang dialami oleh kaum perempuan. Oleh karena itu tidak mengherankan jika persoalan perempuan dapat mengundang rasa simpati yang cukup besar dari masyarakat luas sehingga muncul upaya-upaya untuk memperbaiki kondisi kaum perempuan dengan penyadaran dan pemberdayaan.

Sepanjang sejarah memang tidak banyak perempuan yang menjadi pemikir, pemimpin, kaum ulama, sufi, pahlawan, pemuka dan tokoh masyarakat. Dengan demikian, realitas ini secara sepintas akan menjadi bukti kelemahan eksistensi kaum perempuan di antara kaum laki-laki. Asumsi ini sangat mempengaruhi kaum perempuan dalam sosialisasi citra mereka sebagai manusia yang menginginkan persamaan dalam kehidupan. Perbedaan antara laki-laki dan perempuan seringkali menjadi perdebatan yang hangat dan tak pernah usai. Sebagian pendapat menyamakan dan mensejajarkan antara keduanya, sebagian lagi secara tegas membedakan dalam berbagai hal, dan menganggapnya sebagai kodrat atau takdir. 
Realitas tersebut akan menyisahkan tanya "manakah yang benar? tentu saja keduanya harus dipahami berdasarkan sudut pandang yang digunakan kedua pendapat ini. Pendapat yang menyamakan kedudukan antara laki-laki dan perempuan tentunya memiliki alasan yang substansial dijadikan sebagai dasar untuk menyamakan kedudukan tersebut. Demikian pula dengan pendapat yang membedakan kedudukan antara keduanya. Hal inilah yang akan menjadi bagian dalam perbincangan tentang gender pada tulisan ini.

Kesalahan dalam mempersepsikan persamaan dan perbedaan laki-laki dan perempuan bisa berakibat fatal. Propaganda yang gencar mengenai kesamaan laki-laki dan perempuan, bisa menjadi beban dan justru merugikan kaum perempuan itu sendiri. Sedangkan perbedaan yang digeneralisir dalam semua hal, juga umumnya melemahkan perempuan. Betapa banyak label-label yang dilekatkan pada perempuan yang seolah-olah merupakan kodrat yang umumnya bernada negatif. Selain kurang cerdas dan emosional, perempuan seringkali dianggap boros, santai, penakut, cerewet, tidak tegas, senang menggosip,dan lain-lain (Mansour Fakih, 1996).

Ada dua aliran (mainstream) pandangan stereotip terhadap karakteristik (status dan juga peran) perempuan, yaitu; pertama, teori nature (alam) yang beranggapan bahwa karakter perempuan disebabkan karena faktor biologis dan komposisi kimia dalam tubuh. Perbedaan tersebut menimbulkan perbedaan aspek psikologis dan intelektual. Kalau kaum laki-laki dianggap mempunyai sifat agresif, rasional, independen, percaya diri, pemberani, maka perempuan sebaliknya. Menurut teori ini faktor-faktor tersebut menyebabkan problem ketergantungan. Oleh karena itu, perempuan dianggap sukar untuk maju dan berkembang, sehingga kaum perempuan kurang memiliki peranan dalam lingkungan masyarakat.

Kedua, teori nurture (kebudayaan). Menurut teori ini faktor yang paling menentukan posisi, peran, dan karakteristik perempuan adalah lingkungan dan budaya. Selama ini budaya, pola asuh, struktur masyarakat kurang memberikan dukungan terhadap tumbuh kembangnya potensi perempuan. Sehingga sesungguhnya anggapan kurang cerdasnya perempuan, itu bukan faktor bawaan. Berdasarkna teori ini dapat dipahami bahwa ketidaksetaraan antara kaum laki-laki dan kaum perempuan itu disebabkan karena kesempatan dan peluang yang dimiliki antara keduanya berbeda, sehingga tangga menuju aktualisasi tidak equivalen dan menyebabkan salah satu pihak dianggap subordinat atau kelompok minoritas.

Beberapa penelitian, seperti yang dilakukan oleh Benavot Flora dan Wolf menemukan bahwa, ada banyak keuntungan yang diperoleh oleh negara yang sedang berkembang yang meningkatkan partisipasi anak perempuan dalam pendidikan. Dinyatakan bahwa, perempuan yang berhasil menyelesaikan pendidikan paling tidak tingkat dasar, akan mampu mengakses informasi lebih baik. Dengan demikian ia bisa memperoleh kesempatan kerja yang lebih baik pula. Dengan keadaan ini dapat dipastikan pendapatannya akan meningkat. Sumbangan ekonomi perempuan tidak saja akan berdampak pada meningkatnya income keluarga, tetapi juga dapat mendongkrak Gross National Product (GNP) negara bersangkutan. 
Upaya untuk mendorong perempuan berpartisipasi dalam pendidikan masih menghadapi sejumlah kendala besar. Ideologi gender tersosialisasikan dalam berbagai pranata sistem budaya, interpretasi agama, pranata pendidikan, keluarga dan lembaga sekolah, pranata ekonomi dan hukum. Dalam pranata pendidikan, keluarga misalnya, sejak dini telah menekankan kecendrungan pembedaan peran bagi anak laki-laki dan perempuan. Demikian pula perlakuan guru/pendidik terhadap murid atau mahasiswa dalam media pembelajaran misalnya buku Bahasa Indonesia di sekolah dasar: Teks yang dimuat berbunyi antara lain: "Anak laki-laki membantu ayah bekerja atau membaca koran. Sementara anak perempuan membantu ibu di dapur".

Hal seperti tersebut di atas yang dimaksudkan oleh teori Nurture bahwa realitas perbedaan itu dikarenakan oleh pembiasaan yang akhirnya secara dogmatis dapat berpengaruh secara mendalam dalam pemahaman setiap orang. Jika digambarkan seorang anak perempuan selalu dengan bersentuhan pekerjaan atau kegiatan domestic, maka pembiasaan ini akan menjadi acuan bagi mereka untuk mencitrakan diri, meskipun kita temukan realitas bahwa kebanyakan tukang masak atau master chef itu adalah kaum laki-laki.

Masih berkaitan dengan masalah di atas, sejalan dengan teori menurut para feminis, terdapat kekeliruan yang mendasar terhadap persoalan perbedaan laki-laki dan perempuan. Ada perbedaan antara faktor yang disebut kodrat dan apa yang sekarang populer disebut gender. Kodrat merujuk pada perbedaan jenis kelamin yang ditentukan berdsarkan aspek biologis ini melekat pada jenis kelamin tertentu, sehingga tidak dapat dipertukarkan, contohnya perbedaan pada organ reproduksi. Perempuan alat reproduksinya berupa rahim, vagina dan payudara yang memungkinkan perempuan dapat mengandung, melahirkan dan menyusui. Sedangkan organ reproduksi laki-laki sangat berbeda. Hal inilah yang dimaksud dengan kodrat, ketentuan dan ciptaan Allah yang tidak dapat berubah, mutlak dan tanpa kecuali.

Faktor kedua (gender) merupakan perbedaan laki-laki dan perempuan yang ditentukan berdasarkan anggapan dalam kehidupan social masyarakat, karena pola sosial dan budaiya. Misalnya laki-laki dianggap kuat, memiliki akal rasional, dan perkasa, sedangkan perempuan selalu identik dengan karakter lembut, perasa dan emosionall. Dalam kenyataannya, tidak semua laki-laki lebih cerdas atau lebih pintar daripada perempuan. Sebaliknya, ada juga laki-laki yang emosional dan lemah lembut. Pandangan tentang kehebatan dan kelebihan (superioritas), dan kelebihan akal tidak bersifat mutlak dan bukan sesuatu yang kodrati. Sehingga dapat dipahami bahwa yang membedakan antara kaum laki-laki dan kaum perempuan itu hanyalah batasan hal-hal yang bersifat kodrati tersebut. Selain itu, semua hal dapat disamakan proporsi dan posisinya, baik dalam hal domestik maupun ranah publik.

Mencermati dua aliran pemikiran tersebut, tampaknya kita perlu jeli melakukan analisis. Pandangan ekstrim bahwa faktor biologis yang menentukan sifat perempuan tentu saja tidak sepenuhnya dapat dibenarkan. Fakta membuktikan bahwa tidak $100 \%$ perempuan kurang cerdas, emosional, dan lain-lain. Meski dalam jumlah tidak banyak, ada perempuan-perempuan dalam lintasan sejarah yang memiliki keutamaan dan sangat 
berperan dalam masyarakat. Bukankah Aisyah istri Rasulullah adalah seorang yang cerdas, bukankah sejarah Indonesia sendiri memiliki Tjoet Nyak Dien, pahlawan Aceh terkenal yang pemberani.

Kurangnya perempuan yang "berhasil” bukan karena tidak berpotensi melainkan karena kurangnya kesempatan yang diberikan untuk berkembang. Perempuan menjadi tidak cerdas justru karena dianggap bodoh. Ketika masyarakat makin menyadari pentingnya pendidikan dan memberikan kesempatan untuk belajar, banyak perempuan yang mengungguli laki-laki. Bahkan ada hasil penelitian yang menyebutkan bahawa anak perempuan lebih banyak yang tekun dan berprestasi di dalam dunia pendidikan.

\section{Pandangan Islam tentang Gender}

Wacana gender di lingkungan umat Islam ditanggapi secara beragam; ada yang merespon secara positif dan menerimanya sebagai kemestian sejarah, namun juga ada yang meresponnya secara negatif dan secara apriori menolaknya karena dianggap sebagai sesuatu yang datang dari Barat yang akan merusak Islam. Di luar dua sikap yang ambivalen itu, terdapat model ketiga dalam merespon wacana gender, yaitu sikap kritis. Respon tersebut wajar muncul karena sebagai istilah, gender merupakan wacana baru di lingkungan umat Islam.

Kenyataan terhadap respon di atas tampaknya berangkat dari kegelisahan sekaligus kekhawatiran masyarakat terhadap pudarnya sakralitas Islam, karena mereka umumnya meyakini bahwa Islam adalah sistem ajaran yang sudah lengkap, paripurna, dan tidak kurang suatu apa. Tidak ada satu persoalan apapun, besar maupun kecil, yang mencolok maupun yang remang-remang, yang belum ada jawabannya (Lihat Q.S. AlMa'idah: 1). Persoalannya adalah bagaimana memahami teks tersebut dalam hubungannya dengan gender. Apakah gender bagian dari Islam, apakah Islam memiliki pandangan mengenai gender dan beberapa pertanyaan yang menggelayut lainnya.

Dalam al-Qur'an disebutkan bahwa laki-laki dan perempuan adalah zauj; berpasangan. Teori pandangan ini menunjukkan bahwa laki-laki dan perempuan merupakan setara dan bersifat komplementaris (saling melengkapi). Allah menciptakan segala sesuatu dengan berpasang-pasangan. Laki-laki-perempuan, suami-istri, siangmalam, bumi-langit, malam-siang,positif-negatif, kaya-miskin dan sebagainya. Keberpasangan mengandung perbedaan sekaligus persamaan. keberpasangan bukan sesuatu yang bersifat suplemen, namun bersifat komplemen. Karena itu, perbedaan dan persamaan dalam keberpasangan merupakan sesuatu yang given, agar kehidupan berjalan baik dan seimbang, dalam realitanya akan selalu terjadi tidak dapat di hindari. Keberpasangan dengan perbedaan merupakan karunia yang selalu ada.

Laki-laki dan perempuan keduanya berkewajiban menciptakan situasi harmonis dalam keluarga dan masyarakat. Ini berarti kita dituntut untuk mengetahui keistimewaan dan kekurangan masing-masing, serta perbedaan-perbedaan antar keduanya. Tanpa mengetahui hal-hal tersebut, maka orang bisa mempermasalahkan dan menzalimi banyak pihak. Dia bisa menganiaya perempuan karena mengusulkan hal-hal yang justru bertentangan dengan kodratnya. 
Tak ada satu ayat pun dalam Al-qur'an yang mengatakan sifat wanita dan laki-laki merupakan ketentuan atau kodrat. Yang secara tegas dan eksplisit dinyatakan bahwa baik laki-laki maupun perempuan memiliki potensi untuk beriman dan bertakwa (Lihat Q.S An-Nisa: 124)

Perbedaan yang terlihat antara laki-laki dan perempuan berdasarkan karakter atau sifat yang muncul dari pembawaan tidak dapat dijadikan sebagai barometer dalam menentukan posisi atau kedudukan seseorang dalam berperan pada lingkungan masyarakat. Apabila hal tersebut terjadi maka dapat merugikan atau mendiskreditkan salah satu pihak. Padahal nash al-Qur'an tersebut telah menjelaskan persamaan potensi yang dimiliki seseorang (Hasnani Siri, 2014).

Berdasarkan pemahaman di atas maka perempuan diciptakan Allah untuk mendampingi lelaki, demikian juga sebaliknya. Dengan model hubungan ini, maka tidak ada satu pihak yang menegasikan pihak lainnya. Kedua pihak merupakan pasangan yang simbiose mutualisme. Hal ini karena ciptaan Allah pasti yang paling baik dan sesuai untuk masing-masing. Perempuan pastilah yang terbaik untuk mendampingi laki-laki, sebagaimana pula lelaki adalah yang terbaik menjadi pendamping perempuan. Tidak ada ciptaan Allah yang tidak sempurna dalam potensinya mengemban tugas serta fungsi yang diharapkan dari ciptaan itu. Sang Maha Pencipta Maha Mengetahui kebutuhan laki-laki dan perempuan serta apa yang terbaik lagi sesuai dengan masing-masing. Dia pula yang memberi petunjuk untuk tercapainya dambaan kedua jenis kelamin itu, antara lain berupa ketenangan dan ketentraman hidup.

Meskipun seharusnya seperti dikemukakan di atas, namun dalam realitas sosialnya, kedua jenis kelamin, laki-laki dan perempuan sering tidak berjalan seiring, sehingga berakibat pada terjadinya tindak kekerasan terhadap salah satu pihak, terutama kepada perempuan. Ironisnya, tindakan itu sering dirujukkan pada teks-teks otoritatif, al-Qur'an dan Hadis Tentu saja ada sebagian masyarakat yang merujuk alQur'an untuk dasar tindakannya yang tidak benar, bukan kedua sumber itu yang salah, namun lebih pada pemahamannya yang kurang tepat dan relevan. Untuk itu, merupakan keharusan untuk rethinking terhadap paham-paham tersebut, dengan maksud agar tujuan agama tidak tereduksi dan terdistorsi.

Seperti yang telah dijelaskan sebelumnya, ajaran bahwa laki-laki dan perempuan itu adalah setara. Namun ajaran ini sering diabaikan dan dikalahkan oleh adanya teks lain yang menyatakan sebaliknya, baik dari al-Qur'an seperti ar-rijalu qowwamuna (QS. An-Nisa: 11) dan waqorna fi buyutikunna (QS. Al-Ahzab : 33) dan Hadis seperti tidak akan sukses, bangsa atau masyarakat yang menyerahkan urusannya kepada perempuan. Tak pelak, pemahaman yang hegemonik terhadap tiga contoh teks terakhir tersebut telah melahirkan berbagai perilaku diskriminatif terhadap perempuan.

Islam hadir sebagai agama yang didasarkan pada teks atau nash. Teks tersebut adalah al-Qur'an dan Hadis atau Sunnah Nabi. Al-Qur'an dan Hadis merupakan dua hal pokok dalam seluruh bangunan dan sumber keilmuan Islam. Sebagai sesuatu yang sentral dalam jantung umat Islam, adalah wajar dan logis bila perhatian dan 
apresiasi terhadapnya melebihi perhatian dan apresiasi terhadap bidang lainnya. AlQur'an dan Hadis merupakan sumber inspirasi dan ajaran bagi umat Islam.

Hadirnya al-Qur'an, Hadit's dan ijma para Ulama, di tengah-tengah masyarkat yang multi kultural, ini merupakan rahmat tuhan yang maha Esa untuk membimbing dan menjadikan tolak ukur agar kehidupan social individu maupun kelompok berjalan dengan seimbang dan damai. Tidak ada diskriminasi baik perseorangan maupun kelompok, al-Qur'an maupun Hadis memiliki visi misi yang sama yang bersifat universal, meskipun terkadang keduanya merespon peristiwa yang bersifat temporal dan partikularistik. Visi inilah yang merupakan hal penting dalam kehadiran, termasuk dalam etika tuntunan relasi laki-laki dan perempuan untuk mencapai kehidupan yang harmonis,

Dari paradigma Islam tersebut di atas, maka ditemukan beberapa prinsip kesetaran gender dalam Islam:

1. Laki-laki dan perempuan sama-sama sebagai khalifah Allah sebagaimana ditegaskan QS. al-An'am: 165 dan al-Baqarah: 30.

2. Laki-laki (Adam) dan perempuan (Hawa) sama-sama terlibat aktif dalam peristiwa drama kosmis, sebagaimana terekam dalam banyak ayat seperti QS. al-Baqarah: 35, al-A'raf: 20 dan 22, serta 23 dan al-Baqarah: 187

3. Laki-laki dan perempuan berpotensi yang sama dalam meraih prestasi sebagaimana terdapat dalam QS. Ali-Imran: 195, an-Nisa: 124, an-Nahll: 97 dan Ghafir:40.

4. Laki-laki dan perempuan sama-sama menerima perjanjian primordial sebagaimana ditegaskan dalam QS. al-A"raf:172.

Secara khusus untuk prinsip yang terakhir, dikaitkan dengan dunia pendidikan maka kaum perempuan dan laki-laki memiliki peluang yang sama untuk mengaktualisasikan diri dalam memperlihatkan kompetensinya masing-masing. Dalam agama Islam, wanita diwajibkan menuntut ilmu pengetahuan seperti halnya kaum pria. Agama Islam telah menyamakan wanita dan pria dalam hal-hal yang bersifat kerohanian dan kewajiban-kewajiban keagamaan tanpa perbedaan dalam ilmu dan pendidikan (M. Athiyah al-Abrasyi, 1974). Senada dengan hal tersebut Nasaruddin Umar yang menyatakan bahwa Islam memberikan ketegasan bahwa prestasi individual, baik dalam bidang spiritual maupun urusan karir profesional, tidak mesti dimonopoli oleh salah satu jenis kelamin saja, akan tetapi baik laki-laki maupun perempuan berhak memperoleh kesempatan yang sama meraih prestasi optimal.

Hal ini senada dengan ungkapan Qasim Amin dalam bukunya Tahrir al-Mar'ah. Yang berarti: "Sesungguhnya kaum wanita tidak akan mampu mengatur rumah tangganya kecuali dia telah memperoleh ilmu pengetahuan, etika, dan adab. Maka mereka wajib belajar seperti halnya yang dipelajari oleh kaum laki-laki sekurangkurangnya dari pendidikan dasar sehingga mereka memiliki penjelasan pada bagianbagian keilmuan, supaya mereka dapat memilih sesuatu yang sesuai dengan keinginannya, dan mampu mengerjakan sesuatu dengan teliti." 
Ide pembaharuan yang diangkat oleh Qasim Amin mangarah pada emansipasi wanita dengan latar belakang pemikiran yang bertujuan untuk memperbaiki derajat kaum wanita yang dipandang sangat rendah. Baik dalam status dan peranan sosial maupun dalam hak dan kewajiban pada berbagai bidang. Sebagaimana yang diungkapkan dalam bukunya bahwa wanita adalah manusia yang sama seperti laki-laki, tidak ada yang membedakan antara keduanya dalam hal anggota tubuh, sifat-sifatnya, pikirannya, kecuali dalam hal yang sifatnya kodrati dan berhubungan dengan atribut biologisnya (Harun Nasution, 1975).

\section{Keadilan dalam Islam}

Dalam Islam, prinsip keadilan tidak dapat terlepas dari ajaran tauhid. Tauhid adalah tindakan yang menegaskan bahwa Allah itu Esa, Pencipta yang mutlak dan transenden, Penguasa dari segala yang ada, sementara yang lain adalah makhluk atau ciptaan-Nya (Isma'il Raji al-Faruqi, 1995). Allah Sang Pencipta memiliki entitas yang jelas berbeda dengan makhluk-Nya. Pembedaan ini membawa konsekuensi bahwa tidak ada yang setara dengan Allah, sementara semua manusia (laki-laki dan perempuan), kedudukannya setara sebagai makhluk-Nya. Segala aktivitas manusia akan terikat dan menjalani hidup sesuai dengan kehendak Tuhan. Semuanya samasama mengemban tugas dan tanggung jawab. Yang membedakannya terletak pada nilai ketakwaannya (Q.S. al-Hujurat: 13).

Berbeda dengan kaum feminis yang berpandangan bahwa laki-laki dan perempuan adalah dua individu yang berdiri sendiri, sementara Islam memandang perempuan dan laki-laki itu adalah dua entitas yang berpasangan. Sebagaimana layaknya ciptaan lain yang juga berpasangan (QS. al-Dzariyat: 49 dan al-Rum: 21). Maksudnya bahwa keduanya memiliki persamaan sekaligus juga perbedaan. Mereka sama karena kedudukannya sebagai hamba Allah (QS. al-Dzariyat: 13, al-An'am: 165, dan alBaqarah: 30). Mereka memiliki hak, tugas, dan tanggung jawab yang sama akan hal tersebut. Akan tetapi keduanya berbeda fungsi, sesuai dengan fitrah atau kodrat masing-masing. Fitrah atau kodrat manusia dalam Islam tidak sekedar fisik semata, melainkan psikis dan rohani juga (Baharuddin, 2014). Selain itu berpasangan juga mengandung arti bahwa tiap individu saling membutuhkan satu dengan yang lain. Tidak dapat berdiri sendiri dan tidak lengkap tanpa kehadiran yang lain.

Pada dasarnya sifat patriarkat dan matriarkat itu positif, hanya saja kemudian menjadi negatif ketika dalam kondisi ekstrem. Sifat patriarkat yang positif adalah kecenderungannya ingin melindungi, menjaga, mandiri. Jika terlalu ekstrem yang terjadi adalah sifat negatifnya akan muncul, yakni otoriter dan penindas. Sementara sifat positif matriarkat adalah memiliki kecenderungan ingin merangkul, menyayangi, dan melihat sesuatu sebagai bagian dari kesatuan dengan dirinya. Jika terlalu ekstrem, maka sifat negatif yang akan muncul, yakni terlalu toleran, termasuk dapat melanggar norma baik buruk, dan tidak memperhatikan hukum.

Islam adalah agama yang menjaga agar keberadaan patriarkat dan matriarkat tetap lestari dan berjalan secara seimbang dan harmonis. Hal ini berbeda dengan tujuan yang 
hendak dicapai oleh feminis. Feminis berupaya untuk meruntuhkan budaya patriarkat dan menuntut persamaan dan kebebasan perempuan. Sementara keadilan Islam berupaya menyeimbangkan karakter patriarkat dan matriarkat dengan aturan yang telah ditetapkan dalam syariat. Sedang tujuan utamanya adalah mengarahkan agar laki-laki dan perempuan mampu menjalankan tugasnya sebagai hamba Allah sebaik mungkin, yakni sesuai dengan fitrah mereka masing-masing.

Di samping itu, kaum feminis selalu menganggap patriarkat dan matriarkat dengan sudut pandang yang negatif. Patriarkat dipandang bersifat otoriter dan menindas, sehingga harus diruntuh-kan. Sementara matriarkat bersifat lemah, maka harus ditinggal-kan. Akan tetapi cara yang ditempuh oleh feminis adalah dengan mengarahkan perempuan untuk menempati dunia laki-laki dan meniru cara hidup mereka. Inilah ketidakkonsistenan kaum feminis. Mereka bukanya meruntuhkan sistem patriarkat melain-kan justru melegalkannya dengan mengubah wujud perempuan menjadi seperti laki-laki.

Aturan hukum agama Islam berpegang atas prinsip bahwa Islam, dalam masalah relasi pria dan wanita, bersifat patriarkat sekaligus juga matriarkat. Keduanya saling mengisi dan saling membantu. Ketimpangan terjadi bila telah terjadi sesuatu yang tidak seimbang di antara keduanya. Seperti pada saat Islam pertama kali datang di Jazirah Arab. Pada Masa Jahiliyah, perempuan dipandang sebelah mata. Budaya yang berkembang pada masa itu adalah budaya patriarkat yang negatif. Dalam masyarakat Arab, laki-laki bertugas membela dan mempertahankan seluruh anggota keluarga, bertanggung jawab memenuhi seluruh kebutuhan anggota keluarga. Konsekuensinya laki-laki memonopoli kepemimpinan dalam semua tingkatan, mulai dari kepala rumah tangga dan masyarakat. Promosi karier dalam berbagai profesi dalam masyarakat hanya bergulir di kalangan laki-laki. Perempuan hanya bertugas dengan tugas-tugas reproduksi. Jadi, laki-laki memiliki kesempatan lebih besar dibanding perempuan untuk memperoleh prestasi dan prestise dalam masyarakat (M. Hajir Mutawakkil, 2014).

Islam datang dengan membawa perubahan; yakni mengembalikan stabilitas sosial masyarakat. Banyak kasus-kasus hukum yang diubah dan itu justru menguntungkan perempuan.

Perempuan juga diberi peran agar eksis dalam membangun masyarakat. Misalnya, pembunuhan bayi perempuan yang lazim terjadi pada masyarakat Jahiliyah dihilangkan. Bayi perempuan juga disambut kehadirannya dengan akikah, suatu tradisi syukuran kelahiran bayi yang sebelumnya hanya untuk bayi laki-laki. Islam juga sangat menghargai perempuan untuk memilih jodoh yang disukai. Maskawin dalam Islam diakui sebagai hak milik pribadi perempuan, baik dalam status sebagai istri maupun mantan istri. Ketika menjadi istri, hak perempuan juga dijamin dan wajib dipenuhi, seperti pangan, sandang, dan papan. Perempuan yang pada Masa Jahiliyah dijadikan harta warisan. Pihak mendiang suami berhak atas diri perempuan apakah mau dikawini salah satu keluarga atau menebus dirinya kepada mendiang keluarga suami agar dapat menikah dengan orang lain. Selain itu, nilai reproduksi perempuan juga dihargai. Posisi seorang Ibu, jauh lebih mulia derajatnya daripada seorang ayah (Musdah Mulia, 2011). 


\section{Konsep Bias Gender dalam Al-Qur'an}

Gender adalah pandangan atau keyakinan yang dibentuk masyarakat tentang bagaimana seharusnya seorang perempuan atau laki-laki bertingkah laku maupun berpikir. Misalnya: pandangan bahwa perempuan ideal harus pandai memasak, pandai merawat diri, lemah lembut, atau keyakinan bahwa perempuan adalah makhluk sensitif, emosional, selalu memakai perasaan. Sebaliknya seorang laki-laki sering dilukiskan berjiwa pemimpin, pelindung, kepala rumah tangga, rasional, tegas dan sebagainya. Dengan singkat gender secara jenis kelamin sosial yang dibuat masyarakat, yang belum tentu benar (Lihat Q.S Al-Isra: 70).

Bahwa Allah telah menciptakan laki-laki dan perempuan dengan bentuk yang terbaik dengan kedudukan yang paling hormat. Manusia juga diciptakan mulia dengan memiliki akal, perasaan dan menerima petunjuk. Oleh karena itu al Qur'an tidak mengenal pembedaan antara laki-laki dan perempuan, karena di hadapan Allah adalah sama. Laki-laki dan perempuan mempunyai derajat dan kedudukan yang sama, dan yang membedakan antara laki-laki dan perempuan hanyalah dari segi biologisnya (Nasaruddin Umar, 2002). Adapun dalil-dalil al-Qur'an yang mengatur tentang kesetaraan gender adalah:

1. Tentang hakikat penciptaan laki-laki dan perempuan surat al-Rum ayat 21, surat an-Nisa' ayat 1, surat al-Hujurat ayat 13 yang intinya berisi bahwa Allah SWT telah menciptakan manusia berpasang-pasangan yaitu laki-laki dan perempuan, supaya mereka hidup tenang dan tentram, agar saling mencintai dan menyayangi serta kasih dan mengasihi, agar lahir dan menyebar banyak laki-laki dan perempuan serta agar mereka saling mengenal. Ayat-ayat di atas menunjukkan adanya hubungan yang saling timbal balik antara lelaki dan perempuan, dan tidak ada satupun yang mengindikasikan adanya superioritas satu jenis atas jenis lainnya.

2. Tentang kedudukan dan kesetaraan antara laki-laki dan perempuan Surat Ali Imran ayat 195, surat an-Nisa' ayat 124, surat an-Nahl ayat 97, surat at-Taubat ayat 71-72, surat al-Ahzab ayat 35. Ayat-ayat terssebut memuat bahwa Allah SWT secara khusus menunjuk baik kepada perempuan maupun laki-laki untuk menegakkan nilai-nilai Islam dengan beriman, bertaqwa dan beramal. Allah SWT juga memberikan peran dan tanggung jawab yang sama antara laki-laki dan perempuan dalam menjalankan kehidupan spiritualnya. Dan Allahpun memberikan sanksi yang sama terhadap perempuan dan laki-laki untuk semua kesalahan yang dilakukannya. Jadi intinya kedudukan dan derajat antara lakilaki dan perempuan di mata Allah SWT adalah sama, dan yang membuatnya tidak sama hanyalah keimanan dan ketaqwaannya.

Sedangkan gender dalam al-Qur'an menurut Dr. Nasaruddin Umar dalam Jurnal Pemikiran Islam tentang Pemberdayaan Perempuan (2000) ada beberapa hal yang menunjukkan bahwa prinsip-prinsip kesetaraan gender ada di dalam al-Qur'an, yaitu:

1. Perempuan dan laki-laki sebagai khalifah di bumi kapasitas manusia sebagai khalifah di muka bumi (khalifah fil al 'ard) ditegaskan dalam QS. al-An'am: 165 
dan dalam QS. al-Baqarah: 30. Dalam kedua ayat tersebut, kata "khalifah" tidak menunjuk pada salah satu jenis kelamin tertentu, artinya baik perempuan maupun laki-laki mempunyai fungsi yang sama sebagai khalifah, yang akan mempertanggungjawabkan tugas-tugas kekhalifahannya di bumi.

2. Perempuan dan laki-laki menerima perjanjian awal dengan Tuhan. Perempuan dan laki-laki sama-sama mengemban amanah dan menerima perjanjian awal dengan Tuhan, seperti dalam QS. al-A'raf: 172, yakni ikrar akan keberadaan Tuhan yang disaksikan oleh para malaikat. Sejak awal sejarah manusia dalam Islam tidak dikenal adanya diskriminasi jenis kelamin. Laki-laki dan perempuan sama-sama menyatakan ikrar ketuhanan yang sama. Qur'an juga menegas kan bahwa allah memuliakan seluruh anak cucu Adam tanpa pembedaan jenis kelamin. (QS. al-Isra': 70).

3. Perempuan dan laki-laki sama-sama sebagai hamba menurut QS. al-Dzariyat: 56. Dalam kapasitas sebagai hamba tidak ada perbedaan antara laki-laki dan perempuan. Keduanya mempunyai potensi dan peluang yang sama untuk menjadi hamba ideal dalam al-Qur'an bisa diistilahkan sebagai orang-orang yang bertaqwa (muttaqin), dan untuk mencapai derajat muttaqin ini tidak dikenal adanya perbedaan jenis kelamin, suku bangsa atau kelompok etnis tertentu, sebagaimana disebutkan dalam QS. Al-Hujurat [49]: 13.

4. Perempuan dan laki-laki sama-sama berpotensi meraih prestasi maksi-mum tidak ada pembedaan antara laki-laki dan perempuan, ditegaskan secara khusus dalam tiga ayat, yakni Ali Imran 195, an-Nisa' 124, an-Nahl 97. Ketiganya mengisyaratkan konsep kesetaraan gender yang ideal dan memberikan ketegasan bahwa prestasi individual, baik dalam bidang spiritual maupun karier profesional, tidak mesti didominasi oleh satu jenis kelamin saja (Lily Zakiyah Munir, 2002).

Munculnya ketidakadilan terhadap perempuan dengan dalih agama disebabkan karena adanya implementasi yang salah satu dari ajaran agama tersebut yang disebabkan oleh pengaruh faktor sejarah, lingkungan budaya dan tradisi yang patriarkhi di dalam masyarakat, sehingga menimbulkan sikap dan perilaku individual yang secara turun temurun menentukan status kaum perempuan dan ketimpangan gender tersebut. Hal inilah yang kemmudian menimbulkan mitos-mitos salah yang disebarkan melalui nilai-nilai dan tafsir-tafsir ajaran agama yang keliru mengenai keunggulan kaum lelaki dan melemahkan kaum perempuan.

Al-Qur'an tidak mengajarkan diskriminasi antara lelaki dan perempuan sebagai manusia. Di hadapan Allah lelaki dan perempuan mempunyai derajat dan kedudukan yang sama. Oleh karena itu pandangan-pandangan yang menyudutkan posisi perempuan sudah selayaknya diubah, karena al Qur'an selalu menyerukan keadilan, keamanan dan ketenteraman, meng-utamakan kebaikan dan mencegah kejahatan. Ayat-ayat inilah yang digunakan maqasid al Syari'ah atau tujuan-tujuan utama syari'at. Jika tidak ada penafsiran yang tidak sejalan dengan prinsip-prinsip 
keadilan dan hak asasi manusia, maka penafsiran itu harus ditinjau kembali $(\mathrm{Hj}$. Mursyidah Thahir, 2000).

\section{Konsep Gender dalam al-Qur'an}

Di dalam ayat-ayat Al-Qur'an maupun sunnah yang merupakan sumber utama ajaran Islam, terkandung nilai-nilai universal yang menjadi petunjuk bagi kehidupan manusia dulu, kini dan akan datang. Nilai-nilai tersebut antara lain nilai kemanusiaan, keadilan, kemerdekaan, kesetaraan dan sebagainya. Dalam Kaitannya dengan nilai keadilan dan kesetaraan, Islam tidak pernah mentolerir adanya perbedaan atau perlakuan diskriminasi diantara umat manusia. Berikut ini beberapa hal yang perlu diketahui mengenai kesetaraan gender dalam Al-Qur'an.

Dalam Al-Qur'an surat Al-Isra ayat 70 yang berbunyi "Bahwa Allah SWT telah menciptakan manusia yaitu laki-laki dan perempuan dalam bentuk yang terbaik dengan kedudukan yang paling terhormat.Manusia juga diciptakan mulia dengan memiliki akal, perasaan dan menerima petunjuk." Oleh karena itu Al-Qur'an tidak mengenal pembedaan antara lelaki dan perempuan karena dihadapan Allah SWT. lelaki dan perempuan mempunyai derajat dan kedudukan yang sama, dan yang membedakan antara lelaki dan perempuan hanyalah dari segi biologisnya.

Adapun dalil-dalil dalam Al-qur'an yang mengatur tentang kesetaraan gender adalah:

a. Tentang kedudukan dan kesetaraan antara lelaki dan perempuan

Pada Surat Ali-Imran ayat 195, surat An-nisa ayat 124, surat An-nahl ayat 97, surat At Taubah ayat 71-72, surat Al-ahzab ayat 35. Ayat-ayat tersebut memuat bahwa Allah SWT secara khusus menunjuk baik kepada perempuan maupun lelaki untuk menegakkan nilai-nilai islam dengan beriman, bertaqwa dan beramal. Allah SWT. juga memberikan peran dan tanggung jawab yang sama antara lelaki dan perempuan dalam menjalankan kehidupan spiritualnya. Allah SWT. memberikan sanksi yang sama terhadap perempuan dan lelaki untuk semua kesalahan yang dilakukannya. Jadi pada intinya kedudukan dan derajat antara lelaki dan perempuan dimata Allah SWT. adalah sama, dan yang membuatnya tidak sama hanyalah keimanan dan ketaqwaannya (Rusdi Zubeir, 2012).

b. Tentang hakikat penciptaan lelaki dan perempuan

Pada Surat Ar-rum ayat 21, surat An-nisa ayat 1, surat Hujurat ayat 13 yang pada intinya berisi bahwa Allah SWT telah menciptakan manusia berpasang-pasangan yaitu lelaki dan perempuan, supaya mereka hidup tenang dan tentram, agar saling mencintai dan menyayangi serta kasih mengasihi, agar lahir dan menyebar banyak laki-laki dan perempuan serta agar mereka saling mengenal. Ayat-ayat diatas menunjukkan adanya hubungan yang saling timbal balik antara lelaki dan perempuan, dan tidak ada satupun yang mengindikasikan adanya superioritas satu jenis atas jenis lainnya. 


\section{Kesimpulan}

Pemahaman terhadap wacana gender merupakan hal yang memerlukan analisis yang kuat tentang hal-hal yang menjadi bagian dalam wacana ini. Perbedaan antara kaum perempuan dan kaum laki-laki tidak semestinya dipahami berdasarkan atribut biologis, sehingga pemahaman terhadap gender tersebut akan memberi peluang terjadinya missunderstanding terhadap makna yang termaktub dalam wacana gender tersebut. Gender dapat dipahami sebagai perbedaan yang terlihat antara kaum perempuan dan kaum laki-laki berdasarkan relasi sosial yang lebih terkait dengan nilai dan prilaku.

Pandangan yang menyatakan bahwa Islam telah mendeskriditkan kedudukan perempuan di bawah laki-laki merupakan suatu hal yang tidak dapat diterima. Munculnya perbedaan kedudukan antara laki-laki dan perempuan lebih banyak disebabkan adanya pemahaman keliru dari keberadaan teks suci al-Qur'an dan adanya konstruksi sosial masyarakat yang menginterpretasikan teks suci al-Qur'an secara tekstual. Islam melalui al-Qur'an tidak mengajarkan diskriminasi antara laki-laki dan perempuan sebagai manusia. Konstruk sosial dan agama mendudukkan perempuan pada tempat semestinya, sama halnya dengan membongkar habis sejarah manusia yang telah berlangsung berabad-abad dan yang digugat tidak hanya sistem sosial yang terdiri dari kaum pria, tapi juga dari kaum perempuan itu sendiri. Hal mendasar yang menjadi pembeda antara kaum laki-laki dan perempuan menurut Islam adalah terletak pada kualitas iman dan takwanya. 


\section{Bibliografi}

al-Abrasyi, M. Athiyah. Dasar-Dasar Pokok Pendidikan Islam, Terjemah oleh Prof. H. Bustami A Gani dan Bohar Bahry L.I.S. Jakarta : Bulan Bintang, 1974.

al-Faruqi, Isma'il Raji. Tauhid. Bandung: Pustaka, 1995.

Fakih, Mansour, dkk. Membincang Feminisme Diskursus Gender Perspektif Islam. Surabaya: Risalah Gusti, 1996.

Lopa, Baharuddin. Al-Qur'an dan Hak-hak Asasi Manusia. Yogyakarta: Dana Bhakti Prima Yasa, 1996.

Lopa, Baharuddin. Paradigma Psikologi Islami; Studi tentang Elemen Psikologi dalam alQur'an. Yogyakarta: Pustaka Pelajar, 2004.

Mulia, Musdah. Muslimah Sejati; Menempuh Jalan Islami Meraih Ridha Ilahi. Bandung: MARJA, 2011.

Munir, Lily Zakiyah. Memposisikan Kodrat Perempuan dan Perubahan dalam Perspektif Islam. Bandung: Mizan, 2002.

Nasution, Harun. Pembaruan Dalam Islam: Sejarah Pemikiran dan Gerakan. Jakarta: Bulan Bintang, 1975.

Shihab, M. Quraish. Membumikan al-Qur'an. Bandung: Mizan, 2004.

Shihab, M. Quraish. Perempuan dari Cinta sampai Seks, dari Nikah Mut'ah sampai Nikah dari Bias Lama sampai Bias Baru. Jakarta: Lentera Hati, 2005.

Thahir , Hj. Mursyidah (ed.). Pemikiran Islam tentang Pemberdayaan Perempuan. Jakarta: PP Muslimat NU Kerjasama dengan Logos Wacana Ilmu, 2000.

Umar, Nasaruddin. Argumen Kesetaraan Gender Perspektif al-Qur'an. Jakarta: Paramadina, 2001.

Umar, Nasaruddin. Qur'an untuk Perempuan. Jakarta: Jaringan Islam Liberal (JIL) dan Teater Utan Kayu, 2002.

Zed, Mestika. Metode Penelitian Kepustakaan. Jakarta: Yayasan Obor Indonesia, 2018.

Jurnal:

Mutawakkil, M. Hajir. "Keadilan Islam dalam Persoalan Gender" Jurnal Kalimah 12:1 (2014): 81.

Siri, Hasnani. “Gender dalam Perspektif Islam” Jurnal Al-Maiyyah 7:2 (2014): 236.

Zubeir, Rusdi. “Gender dalam Perspektif Islam” Jurnal An-Nisa'a 7:2 (2012): 112-113. 